\title{
REDUCING THE NUMBER OF UNSCHEDULED REPAIRS OF TRACTION GEAR OF EMU TRAINS BY INTRODUCING MODERN TECHNICAL SOLUTIONS
}

Fjodors MIHAILOVS, Institute of Transport, Riga Technical University, Riga, 1 Kalku Street Riga LV-1658, Latvia, fjodors.mihailov@rtu.lv

Janis EIDUKS, Institute of Transport, Riga Technical University, Riga, 1 Kalku Street Riga LV-1658, Latvia, janis.eiduks_2@ rtu.lv Dmitrijs GORBACHOVS, Institute of Transport, Riga Technical University, Riga, 1 Kalku Street Riga LV-1658, Latvia, dmitrijs.gorbacovs@rtu.lv (corresponding author)

The purpose of this article was to find a solution to the problem of reducing the number of the electric multiple unit (EMU) trains traction drive unscheduled repairs due to the breakage of the M24 bolts of the rubber-cord coupling. For these purposes, it is proposed to develop a device that allows accumulating and transmitting data of the impact forces perceived by the bolts of the rubber-cord coupling and whereby reduce the number of unplanned repairs, as well as the associated rolling stock maintenance financial costs for the JSC «Pasažieru vilciens» railway undertaking. The article presents the initial concept of the design development for a device based on the piezoelectric effect, which will make possible to determine the impact force acting on the M24 bolts of the rubber-cord coupling. The data on the minimum breaking force $\mathrm{P}$ were taken based on the results of determining the shear stress $[\tau]$ - on the shear acting on the M-24 bolts of the rubber-cord coupling fastening. Using the electronic modules included in the designed device, it is planned to provide storage and transmission of information with the further possibility of its processing by a developed PC software or mobile application. However, such devices have a significant drawback - a high development price. For this reason, in order to obtain economic viability, the challenge is creating a device, which cost is limited to 50 Euros. Putting this device into operation would reduce the number of unscheduled repairs therefore reducing the costs experienced by the JSC «Pasažieru vilciens».

Keyword: traction gear, failures, shock vibration sensor, piezoelectric effect.

\section{INTRODUCTION}

At the JSC «Pasažieru vilciens» company operating on the Latvian Railway, one of the main reasons for unscheduled repairs of EMU trains motor cars traction gears is the brakes of M-24 bolts for fastening the rubber-cord coupling (Pegov, Burcev et al., 2003). According to reports. on unscheduled repairs (JSC «Pasažieru vilciens» template FT-22) for the period from 2015 to 2020, 358 cases of unscheduled repairs of motor cars due to the malfunction of the traction drive were registered. Of these cases 158 are the braking of the M-24 bolts for fastening the rubber-cord clutch, which consists $44 \%$ of the total number of traction transmission faults.

Data on the number of unscheduled repairs are shown in Table 1 and Fig. 1.

Table 1. Table of total unplanned repairs of traction gear

\begin{tabular}{|c|c|c|}
\hline Year & $\begin{array}{c}\text { Total number of unscheduled repairs of } \\
\text { traction gear }\end{array}$ & $\begin{array}{c}\text { Number of the rubber cord } \\
\text { bolts damage }\end{array}$ \\
\hline 2015 & 55 & 21 \\
\hline 2016 & 53 & 24 \\
\hline 2017 & 54 & 23 \\
\hline 2018 & 63 & 31 \\
\hline 2019 & 51 & 27 \\
\hline 2020 & 63 & 32 \\
\hline$\sum$ & 358 & 158 \\
\hline
\end{tabular}

Copyright (C) 2021 The Authors. Published by Vytautas Magnus University. This is an open-access article distributed under the terms of the Creative Commons Attribution License (CC BY 4.0), which permits unrestricted use, distribution, and reproduction in any medium, provided the original author and source are credited. 


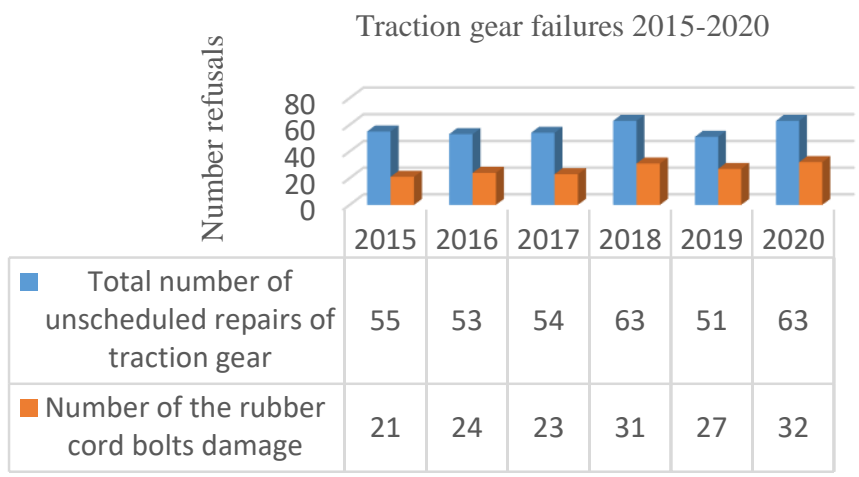

Figure 1. The number of unscheduled repairs of the traction gear and rubber cord coupling bolts in $2015-2020$

\section{PROBLEM}

According to the table, the problem of braking the M-24 bolts of the rubber-cord coupling is predominant for all EMU trains. To significantly reduce, the number of unscheduled repairs, it is necessary to develop a technical solution to reduce the number of unscheduled repairs due to bolt breakage. When an EMU train moves, as a result of the interaction of the track superstructure and the motor car running gear, the bolts of the rubber-cord coupling are constantly subjected to the action of repetitive alternating dynamic and shock loads (Fig. 2). As a result of these loads, the strength of the bolt material decreases sharply and the material of the M-24 bolts works as brittle. After a certain number of alternating load cycles, bolt failure may occur

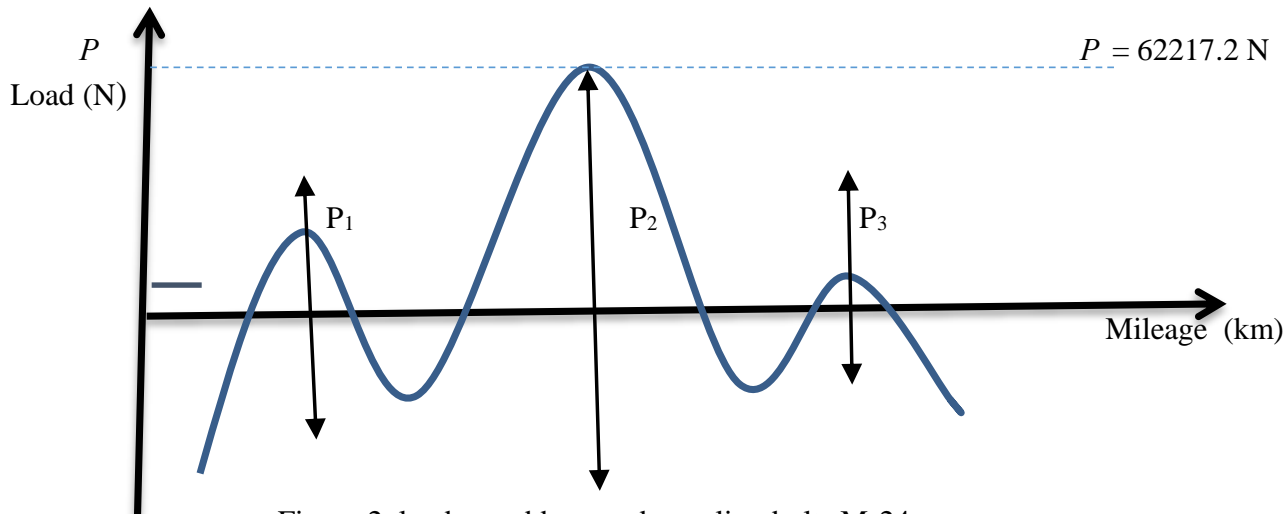

Figure 2. load on rubber-cord coupling bolts M-24.

For these purposes, it is necessary to determine the minimum destructive force $\mathrm{P}$ under the conditions of acting dynamic and shock loads perceiving by the rubber-cord coupling bolts. To determine the loads, calculations were made to find the minimum breaking force (Anurjev V.I., 2001). According to the JSC «Pasažieru vilciens» specification, bolts made of X-45 steel in accordance with GOST 4543-71 (41Cr4 in accordance with EN 10083) must be used for fastening the rubber-cord coupling.

The verification calculation of the cord coupling bolts was carried out according to the shear strength of the bolts:

$$
[\tau] \geq \frac{P}{F}
$$

According to the handbook [2] for steel X-45, the shear stress $[\tau]=135 \mathrm{MPa}=137.6 \mathrm{~N} / \mathrm{mm}^{2}$

$\mathrm{F}$ - cross-sectional area of the bolt

$$
F=\frac{\pi d^{2}}{4}=452.1 \mathrm{~mm}^{2}
$$

Where: $\mathrm{d}$ - bolt diameter $=24 \mathrm{~mm}$

$$
F *[\tau] \geq \mathrm{P}
$$

$$
452.1 * 137.6=62217.2 \geq P \mathrm{~N}
$$

Checking the diameter of bolts from the conditions of shear strength, according to the results of a certain minimum breaking force

$$
d=\sqrt{4 P / \pi}[\tau]
$$




$$
d=\sqrt{\frac{4 * 62217.2}{3.14 * 137.6}}=24 \mathrm{~mm}
$$

According to the data of verification calculations, the diameter of the bolts was selected in accordance with the minimum breaking force, which in the conditions of suburban traffic under the action of variable dynamic and shock loads might be insufficient.

\section{ECONOMIC JUSTIFICATION FOR EQUIPPING SHOCK VIBRATING SENSORS}

To replace the damaged M-24 bolts of the rubber-cord coupling fastening, the motor car must undergo unscheduled repair, which causes its withdrawal from service and large associated costs, the data of financial costs is shown in Table 2

Table. 2. Financial costs for unscheduled repairs during 2015-2020

\begin{tabular}{|c|c|c|c|}
\hline $\begin{array}{l}\text { Replacing the bolts of the } \\
\text { rubber-cord coupling }\end{array}$ & 1 unscheduled repair & For 2020 & For 6 years \\
\hline Amount & 407.09 euro $*$ & 13026.88 euro & 64320.22 euro \\
\hline \multicolumn{4}{|c|}{$\begin{array}{l}* \text { Replacement of rubber-cord coupling bolts }-407.09 € \text { breakdown: } \\
\text { Purchase price of } 1 \text { bolt }-1.09 € \text { : } \\
\text { Use of a shunting locomotive to uncouple the motor car from the train composition and putting it for unscheduled repair }-396 € \\
\text { Additional payment to employees for unscheduled repair }-7 € \\
\text { The cost of electricity consumption for lifting the car }-3 €\end{array}$} \\
\hline
\end{tabular}

In order to reduce the total number of unscheduled repairs and the use of related financial resources due to the replacement of damaged bolts, it is necessary to ensure permanent devices for the condition of rubber - cord coupling bolts monitoring.

To solve the problem of damage to the rubber-cord coupling bolts, it is necessary to develop and implement the following technical solutions:

1. Equipping the rubber-cord coupling flange on the traction motor and gearbox side with 2 shock vibration sensors (4 in total for 1 rubber-cord clutch to control the condition of the rubber-cord coupling and its bolts, with signal transmission to the driver's cab via Bluetooth.

2. The shock vibration sensors can be installed on the rubber cord coupling flange using a threaded connection.

3. The shock vibration sensors can be used to detect the impact load on the bolt connection, as well as to discover the loosening of the rubber-cord coupling bolts.

4. Inviting programmers to develop software and entering the software obtained data into a computer or mobile phone application.

Due to the design features, access to the traction drive during operation and maintenance is complicated, which causes certain problems in determining its technical condition (Fig. 3). Therefore, it is necessary to introduce modern system methods and technical control means in order to obtain up-to-date objective data on the serviceability of the traction drive and its fastening bolts M-24.

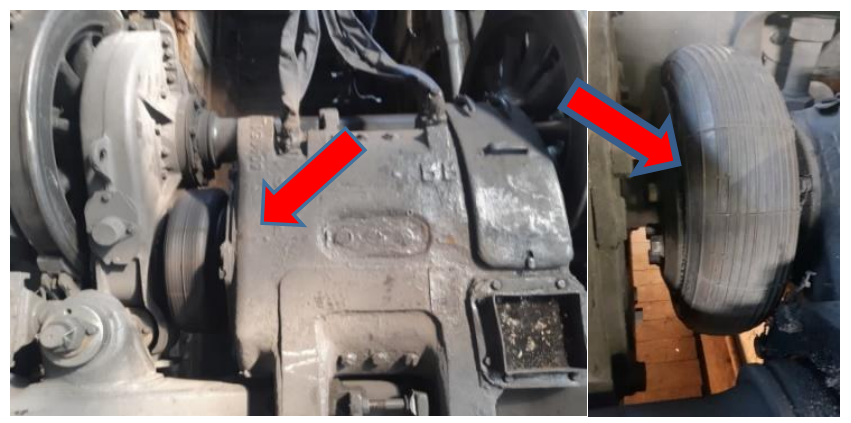

Figure 3. Place for equipment with shock-vibration sensors

\section{THE PRINCIPLE OF OPERATION OF THE SHOCK -VIBRATION SENSOR AND THE COST OF ITS PRODUCTION}

To assess the force of impact on the surface, it is proposed to use devices that convert the value of the acceleration obtained as a result of the impact into the form of an electrical signal. The most common devices for such a transformation are sensors (Popkov V.I, Myshinsky E.L. Vibroacoustic diagnostics, 1989), which use a piezoelectric effect piezoelectric accelerometers, which convert the impact force into an electrical signal, as a result of which the output current or voltage is the accelerometer output informative parameter. Information from the primary transducer (piezoelectric accelerometer), in the form of an electronic signal, is fed to the microcontroller, in which the information 
is processed and stored, and then the processed information is transmitted to the data transmission unit. During maintenance or scheduled preventive maintenance, a tablet computer with installed dedicated software subsequently processes the accumulated information. It shall be also possible to transfer the information using the Bluetooth data transmission system to a computer in the driver's cab or to a mobile device with special application. The signal in the memory is reset once every 2 months (when performing scheduled preventive maintenance TR-1 (Electric train periodical repair and technical servicing regulations L31/97, 1997g.) or once every 1.5-2 years (when performing scheduled preventive maintenance TR-3 (Electric train periodical repair and technical servicing regulations L31/97, 1997g). The schematic diagram of the sensor is shown on Fig. 4, and the prototype of the device is shown on Fig. 5.

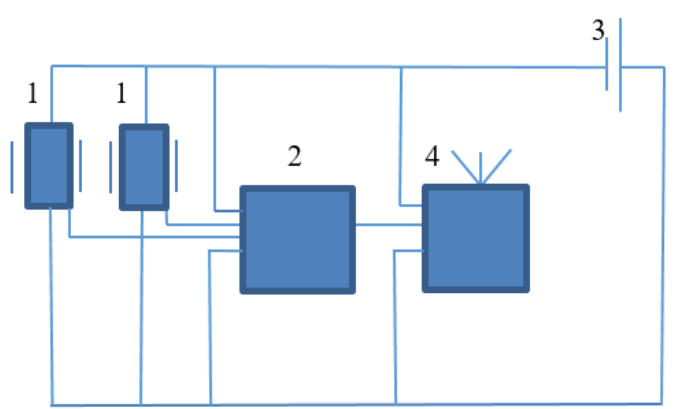

1 - shock sensor 2 pcs; 2 - microcontroller + memory circuit; 3 - power supply unit; 4 data transmission unit

Figure 4. Schematic diagram of the shock-vibration sensor

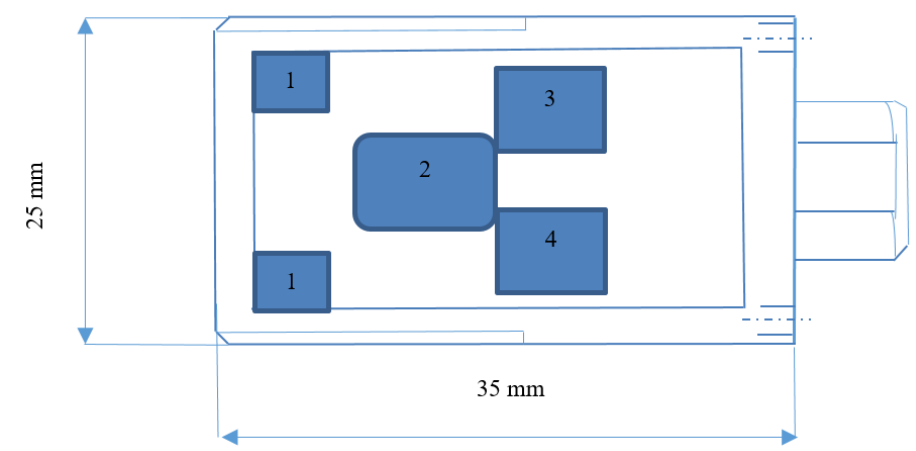

1 - shock sensor 2 pcs; 2 - microcontroller + memory circuit; 3 - power supply unit; 4 data transmission unit

Figure 5. Impact Sensor Prototype

The prototype of the shock sensor is made on the basis of a primary transducer with a shock acceleration range of up to $20 \mathrm{~m} / \mathrm{s}^{2}$, which is rigidly connected to the metal body of the coupling flange by means of a threaded connection. The contact surface of the housing has a hardness index of $\mathrm{HB} \geq 270$ and is made in the form of a cylinder. Upon reaching a certain impact force $\mathrm{P}=55 * 10^{3} \mathrm{~N}(62217.2 \mathrm{~N}-10 \%)$ (Fig. 2). The piezoelectric sensor 1 is triggered and the signal is sent to microcontroller 2, which is designed for processing the electronic digital signal received from the shock sensor and its further storage in a memory device with subsequent sending of data to the driver's cab or to the app of the tablet using data transmission unit 4 (Bluetooth) (Kondratjevs, K., Kunicina, N., et al., 2016). (Fig. 4).

Many researchers in Europe and the United States have studied the problems of improving the operation of vibration sensors. One of the important aspects is the cost of vibration sensors, which are described in articles (Stauffer, J.-M. 2004) and (Leonardson, Ron et al., 1994). The results of the research of these authors' data show the profitability of installing such sensors on various equipment subjected to shock and vibration loads (Zaripov, R., Gavrilovs. P, 2019). Based on the results of the analysis of the articles, the authors decided to make technical proposals for equipping the traction gear of EMU trains with shock vibration sensors to reduce the number of unplanned repairs.

In order to equip all JSC «Pasažieru vilciens» motor cars (65 vehicles) in service, it is necessary to produce a batch of shock-vibration sensors in the amount of $65 * 16=1040$ pcs. Manufacturing costs for one unit will be $30 €$ :

Total amount will be $\sum=30 * 1040=31200 €$

In addition, for the commissioning of impact force sensors, it is necessary:

- To develop the technical design and technical documentation of the sensor with a description of the working principles.

- Develop a sample of vibration sensor.

- Laboratory testing of vibration sensors for possible defects

- Minimization of vibration sensor erroneous actuation.

Total costs of these activities are $\sum=1000 €$

Development of a special mobile application (allowing to receive data from shock-vibration sensors) $-\sum=1500 €$ 
To test the shock vibration sensor in real operating conditions with JSC «Pasažieru vilciens» EMU trains. Determine the final price of equipping a railcar with shock vibration sensors (make a calculation: purchase price of sensors + assembly works 1040 pcs.).

$\sum=15600 €$

Total: $\sum=31200+1000+15600+1500=49300 €$.

Analyzing the information on the costs of equipment with shock-vibration sensors, we can that by installing this sensor on other critical units of the car (Zaripov, R., Gavrilovs, P, 2017.), it is possible to predict a significant reduction in the number of unscheduled car repairs, as well as reduce the cost of car downtime (Gavrilovs, P., Dmitrijevs, 2016). This invention can find application in mechanical engineering, aircraft construction, shipbuilding and other fields for the control and initial determination of the fracture force of bolts (Gavrilovs, P., Ivanovs, V 2017) and (Zaripov, R., Gavrilovs, P et al., 2019).

\section{CONCLUSIONS}

1. The commissioning of a shock-vibration sensor for monitoring the force of impact will allow obtaining objective information about the force of impact (loads) perceived by the M-24 bolts of the rubber-cord coupling. If, when processing during maintenance (scheduled preventive maintenance) the information received from the sensors, a multiple excess of permissible loads is stated, then in such case, the M24 bolts of the rubber-cord coupling must be replaced with new ones. Thus, the possibility of the need to perform unscheduled repairs due to the breakage of the rubber-cord coupling fastening M-24 bolts, which is associated with large financial costs of the enterprise, is prevented.

2. If the project is successfully implemented with a cost not exceeding 50 thousand euros, then within 5 years the project due to the reduction of the number of unscheduled repairs will come to self-sufficiency, and in 6 years it will already bring a profit of 15 thousand euros.

3. In the long run, the finished product can be offered to European and CIS countries for installation of shock vibration sensors on railway and metros rolling stock, as well as with the perspective of installing the shock vibration sensors on the new EMU trains purchased by JSC «Pasažieru vilciens» In addition, this device can be widely used in mechanical engineering, aircraft construction, shipbuilding and other fields for monitoring and initial determination of the fracture force of bolts.

\section{REFERENCES}

1. Anurjev V.I. 2001. Mechanical Engineer Designer Handbook. Mechanical engineering Moscow.

2. Electric train periodical repair and technical servicing regulations L31/97 State stock company « Latvijas dzelzcel̦š̀ Riga 1997g. $152 \mathrm{p}$.

3. Gavrilovs P., Dmitrijevs 2016. A. Research in passenger car bogie central suspension roller and rod base metal and welded metal structure. Engineering for Rural Development, p p. 618-623.

4. Gavrilovs P., Ivanovs V 2017. Research of the defective frog wing of 1/11 mark. Transport Problems, Vol. 12 (4), p 119-126. https://doi.org/10.20858/tp.2017.12.4.12

5. JSC «Pasažieru vilciens» Summary of non-scheduled repairs of electric trains (template FT-22).

6. Kondratjevs K., Kunicina N., Patlins A., Zabasta A., Galkina A. 2016. Vehicle weight detection sensor development for data collecting in sustainable city transport system. 57th International Scientific Conference on Power and Electrical Engineering of Riga Technical University (RTUCON), pp. 1-5 https://doi.org/10.1109/RTUCON.2016.7763136

7. Leonardson R., MacGugan D. 1994. Design and fabrication of a commercial triaxial accelerometer. Sensors, No. 11 (8), pp. $22-23$.

8. Pegov D.V., Burtsev P.V., Andreev V.E. 2003. DC electric trains ЭТ2, ЭТ2M, ЭР2Т, ЭД2Т 2003 Moscow: Transport. 184 p.

9. Popkov V.I, Myshinsky E.L. 1989. Vibroacoustic diagnostics in shipbuilding. Shipbuilding, Leningrad. (In Russian)

10. Stauffer J.-M. 2004. Market opportunities for advanced MEMS accelerometers and overview of actual capabilities vs. required specifications. IEEE PLANS, Position Location and Navigation Symposium, pp. 78-82.

11. Zaripov R., Gavrilovs P, 2019. Study of dynamic characteristics of electric bicycles. Procedia Computer Science, Vol. 149, pp. 307-313. https://doi.org/10.1016/j.procs.2019.01.140

12. Zaripov R., Gavrilovs P. 2017. Research Opportunities to Improve Technical and Economic Performance of Freight Car through the Introduction of Lightweight Materials in their. Construction Procedia Engineering, Vol.187, pp. 22-29. https://doi.org/10.1016/j.proeng.2017.04.345

13. Zaripov R., Gavrilovs P, Sembaev N. 2019. Study of the stressed-deformed condition of a railway tank wagon with shock loading taking into account the decrease of fastenings. Transport Means Proceedings of the International Conference, pp. 1112-1116. 